\title{
先天性エプーリスの1例
}

大藤敬 美* 佐藤研一**

\section{Congenital epulis : report of a case}

\author{
Yoshimi Ofuli*, Kenichi SAto**
}

\section{緒}

言

先天性エブーリスは新生児の虚肉部に先天的に発見さ

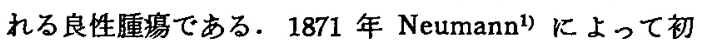
めて報告されて以来, 本邦では約 10 例, 諸外国では数 十例2,わ症例が報告されている，きわめてまれな腫湯 である.その組織像の解积に種々な見解があるが，われ われは顆粒細胞性筋芽腫に相当する本庭の 1 例を経験し たので報告する。

症

例

患者: 生後 2 日目の女性, 新生児

初誩: 昭和 42 年 1 月女日

主訴：上額左側前歯相当部齿肉に発現した球状尰慮

家族歴：両親共に健康, 患者は第 1 子の長女, 特記事 項はない。

現病歴：母覣の妊娠中の経過に特に異常はなかつた。 正常分婏，生下時体重 $2,800 \mathrm{~kg}$.

現症：顔貌正常,身体他部に特に奇形などの異常は㒛 められない， 口腔内所見として歯牙の萠出はない，開口 せしめると上䫑前齿部やや左側の顎堤上に桜挑大の赤色 を帯びた腫瘤があり，有茎性であるが茎部は近遠心的に 比較的広基底性で，䫅舌例的に䔳層である。形は阫円 形で比較的固く, 可動生である，口盐には他に異常は認 められない（写真 1 ).

臨床検查所見：血夜所見としては赤血球数 $495 \times 10^{4}$, 白血球数 12600 ，血色素量 $11.5 \%$, 出血時間 2 分 30 秒, X線所見では腫留に石灰化組織は証明されない，をた同 部未萠出乳掬との関連性も認められない（写真 2 ).

処置およひ経過：新生児黄胆の消失後に切除の予定で

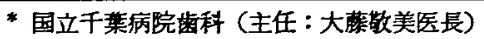

**千藮大学医学部齿科口院外科学教室 (主任 : 掘越蕫郎教授)

* Dental Department, Chiba National Hospital (Chief : Dr. Yoshimi Ofuji)

** Department of Oral Surgery, School of Medicine, Chiba University (Chief : Prof. Tatsuro Horikoshi) 受付 昭和 49 年 9 月 18 日
あったが，初診後腫㨨は茎部でくびれる值向を示し，特 に増殖傾向すなく，生後 16 日目で自然脱落し，その佮 面は自然治嘴した。その後了週間経過を観察したが，同 部の異常は認められなかった・約 8 カ月後では上額乳中，

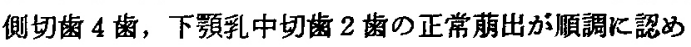
られ, 崡肉部と萠出歯牙形態にす異常がなかった（写真

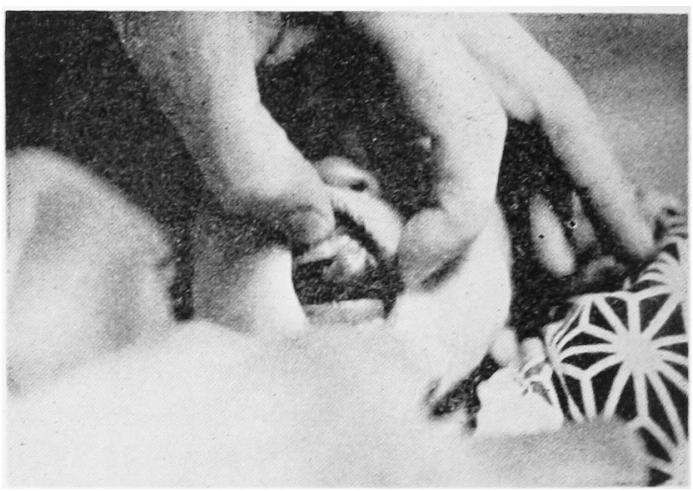

写真 1 初診 時

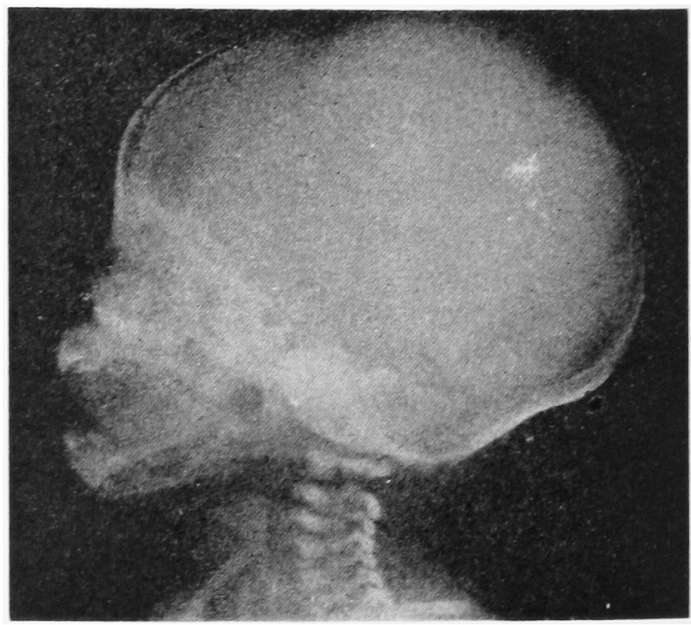

写真 2 初診時レ線写真 


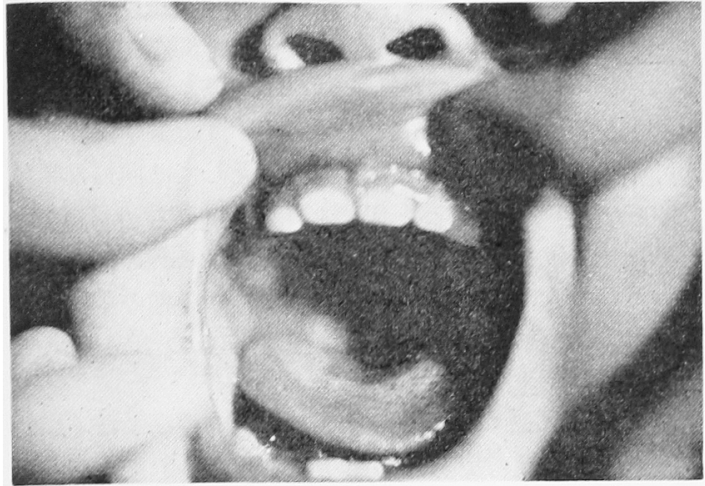

写真 38 力月後口些内

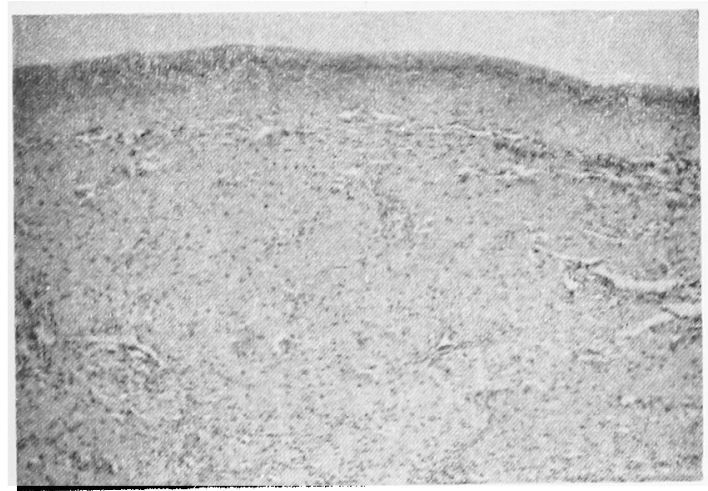

写真 4 組織像 H-E 染色

3).

脱落した腫瘤法肉眼的に球证で， $1.3 \times 1.6 \mathrm{~cm}$ の大き さで, 弾性硬度, X線的に石灰化像は認められなかっ た.

病理組蟣学的所見：腫瘤の表面は比恔的藻層で，粘膜

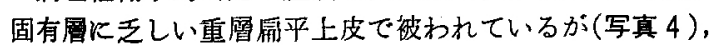

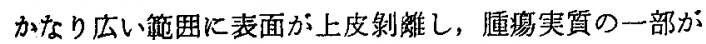

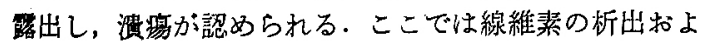
び小円形細胞の漫潤がある。腫焬組織は主として長紡鉦 形細狍からなり，細胞質は豊かでエオシンン淡染し，乙 かる顆粒状である (写真 5，6).この顆粒の一部はPAS 反応陽性であるが䀣夜消化性陰性である。また核はほほほ 細胞内の中央に位置し, 桿棒状, 細胞質に比し小型で, クロマチンむあまり多くない，更に核小体は著明でな い. 堙湯基質は全般にこしく, 腫晹組織の周辺部では, その基質に毛練血管が比校的著しいが，中央部では少な い. 個々の腫掦細胞には膠原線維および㶩銀線維が团続 されている.

個々の腫瘍細包の大きさを測定すると，その横断面の 直径は大きいもので約 $30 \mu$, 平均 $20 \mu$, 綎断面では長 Wすので $100 \mu$, 平均 $50 \mu$ に達する巨大な細胞であ る. 以上の所見からいわ偶顆粒細胞筋芽腫と診断した

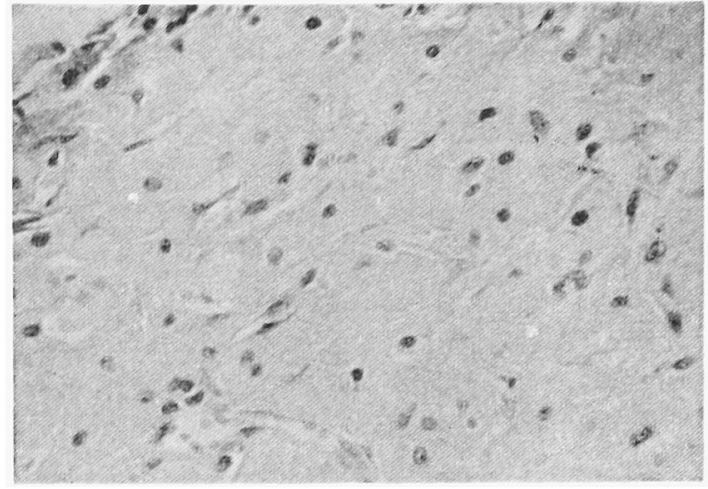

写真 5 組䋐像 $\mathrm{H}-\mathrm{E}$ 染色

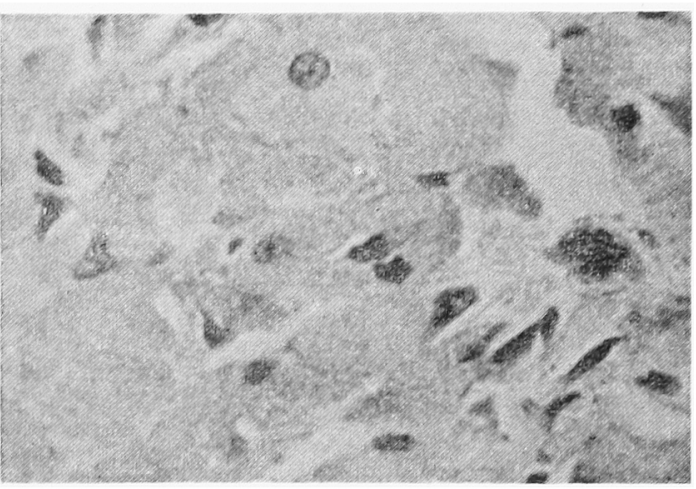

写真 6 組織像 H-E 染色

が，しかし腫浶細胞内には横紋を思わせる構造物は認め られなかった．その他腫瘍組織には上皮の封入や進入增 殖，あるいは石灰化または硬組織の存在は認められなか った。

\section{考察}

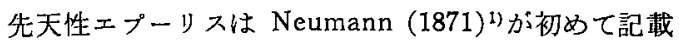
して以来, 諸外国において散見される報告を 1952 年 Custer \& Fust ${ }^{2)}$ が自験例を含めて 47 例集計し, 綜説 を発表した。その後現在までは Bhaskar ら (1955) ${ }^{3)}$ との十数名の報告がある.本邦においては加藤 (1935) 小早川ら $(1956)^{5)}$ ，松田ら $(1955)^{6)}$ ，高橋ら $(1962)^{7)}$, 木村ら $(1963)^{8)}$, 清水ら $(1968)^{9)}$, 枝ら $(1970)^{10)}$, 坂 本ら $(1970)^{11)}$, 西息ら $(1971)^{12)}$, 河村ら $(1971)^{18)}$, 增田ら（1971）吕)の報告があるにすぎない比較的稀れな 疾患である。

本症は新生児，通例女性に多く Crane $5^{15)}$ は 11 例 中 10 例, Bhaskar 5 $5^{3)} 49$ 例中 35 例, 增田 ${ }^{14}$ は 11 例中 5 例が女性であったと報告している。発現部位 は下顎より上顎に多く，主に前幽雪肉部に見られる。臨 床的には型は球形，畉円形まれに分葉形で有茎性であり， その大きさは $0.5 \sim 2.5 \mathrm{~cm}$ 大のものが多い，一般に良 
性で, 悪性化の報告はなく, 切除後再発は認められない. 時に本症は乳歯の萠出に影響することがあると Custer ${ }^{2)}$ が述べている.

われわれの報告例は臨床的に上記の所見に一致し，患 者は女性で発現も上䪽前歯部の球形有茥性腫湯であっ た.腫汪の再発ならびに乳歯萠出にも影響を見なかっ た。

組織学的には先天性エプーリスといわれて来たものに は，単一な組織像を示すものたけでなく，他に種々な entity を含んで来たことが文献上に見受けられる.それ らの組織像の特長から, 成因に種々な考擦が加えられ，

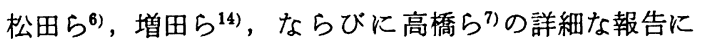
見られるように，大別すると歯原性ならびに非雪原性説 に二分される。

歯胚原説帛としては, Massin（1894）のエナメル上皮 からの上皮腫 (Epitheliom) 説, Schorr (1906) の歯乳 頭および象牙芽細胞説, Kaempher (1911) の象牙芽細 胞説, Cardia (1926) の残存上皮説, Moulonguet ら (1932) のエナメル器説, Custer ら (1952) 2), 松田ら $(1955)^{6)}$ の歯胚の過誤腫説などがある.

非歯胚原説6)としては，Neumann (1871) ${ }^{1)}$ の骨膜から 発生した顎骨の䯣梯肉腫, Füth (1902) の外被細胞説, Klinger（1928）の異個体発生説, Kleine（1929）の歯 肉粘膜の基底細胞説, Jorge (1932) の血管原説, Willis （1948）の外傷説などがある.

本腫瘍の特長の 1 つである顆粒細胞の由来について初 めて言及したのは Sternberg (1928) ${ }^{16)}$ で, 彼は顆粒細 胞性筋芽腫との類似性を説き, ついで Abrikossoff $(1931)^{17)}$ はこれと先天性エプーリスとは同一ののもので あると報告した。 それ以来多くの者は先天性エプーリス は顆粒細胞性筇芽腫の組織像を呈すると報告している.

顆粒細胞性筋芽腫については塩田 ${ }^{18)}$ の詳細な報告があ る.この腫湶の起原については既述した先天性ェプーリ スのそれと一部重複するが. 塩田の報告をここに引用し ておく.

1）筋原説 (Abrikossoff) では本聅患は横紋筋の存在 する部分から発生し, 外傷や炎症に後続する再生あるい は変性により生ずると見た。一方正常の横紋筋が存在し ない部分にも本症が発生するが，この場合は異所性の胎 生横紋筋芽細胞の遗残によるものとした．筋原説の疑問 点は, 外燳などによる筋肉の変性あるいは再生病変であ り腫痬ではない(Willis), あるいは腫㵑細胞に横紋が末 た証明されたことがないこと，横紋筋のないところにも 生ずること,さらに組織化学的および電影的所見でも筋 原性が考えられにくいことなどである。

2）神経原説：Feyter ${ }^{19)}$ ，Fust らは顆粒細胞が神経 線維と密接な関係があるといい, Pearse ${ }^{20)}$ は組織化学 的見地から腫鹪細胞が Schwann 細狍から变化した線維 芽細胞であろらと推論した。Ashburn らも本説に㑆同
したが, Schwann 細胞, 線維芽細胞, 組織球のいつうれ に由来するか不明, Bangle は煩部粘膜下層の末梢有髄 神経線維内に顆粒細胞化の起った小腫湯を認め, 本説を 支持した. その他 Fisher, Garancis は組織学的, 電顕 的に本説を認めている. 本説の反論としては同様な顆粒 細胞がェナハル上皮腫の実質細胞に出現することがあり， その他オンコサイトーマにも見られ, Shear の指摘する ように筋細胞, 線維芽細胞, 上皮細胞の各種の細胞の代 謝障害によつて顆粒細胞の像を呈するすのであるとい 5 .

3）組織球説：Loroux らは本疾患は腫陽でなく顆粒 細胞が新陳代謝の崩壊産物や lipid, glycogen を含んた 組織球性の細胞ではないかと発表した. Holle はそれが 粘液様物質を貯蔵したもの, Bangle は一応神経原説を 考えているが，組織球と極めて類似した性格を示すとい い, Lauche は異常代謝産物を摂取した組織球の尰湯性 増殖であるという。

4）線維芽細胞説：Pearse は perimuscular あるい は perineural fibroblast であると説明し, 本疾患を Granular cell fibroblastoma と呼んでいる. Bauer ら22) は線維芽細胞から腫瘍細胞に移行する像を認めている.

5）多元説 : Shear, Haisken 5, Sobel らは上記の いづれの細胞からも代謝障害によって生ずるという. Toto 5 , Moscovic 5 , Vance 5 , 竹林もほほ同様の 意見である。

以上塩田の報告の概略を引用したが，顆粒細胞性筋芽 腫と先天性エプーリスが組織学的に同一のものとすれば， 上記の各説の冾味が必要となる. 顆粒細胞性筋芽腫は顆

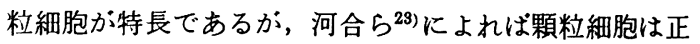
常組織においては, 唾液腺, 上皮小体, 甲状腺なとにみ られ，腫瘍組織においてはオンコサイトーマ, 顆粒細胞 性筋芽腫, 顆粒細胞エナメル上皮腫, 顆粒細胞エナメル 上皮線維腫, 先天性エプーリスなどみられるといら.

河合らの報告によれば, 顆粒細胞の本態について多数 の報告を引用している. それを要約すると, エナメル上 皮腫の顆粒細胞の顆粒については, 脂肪, クリコーゲン を否定する者が多く，此較的不活性物質であり，顆粒出 現は病的角化㙨転であるとするものもあるが，一方これ は酸性多榶類やヶラチン以外の物質であるとする見解も ある.そして最近では顆粒はリポブロティン，糖脂質を 含むものであろうといわれている.

最近の酵素染色, 電顕を用いた研究によると好酸性細 胞やオンコサイトの顆粒は mitochondria であり, 顆粒 細胞性筋芽腫のそれは lysosome であることが明らかに された、また顆粒細胞エナメル上皮腫の原形質顆粒につ いては, mitochondria または lysosome 様のものとい われている. さらに Navarrete ${ }^{24)}$ は各種の顆粒を比較 し，好酸性細胞，オンコサイトはPTAA 染色陽性， PAS 染色陰性で顆粒は mitochondria であり，顆粒細 
胞エナメル上皮腫, 顆粒細胞エナメル上皮線維腫, 顆粒 細胞性筋芽腫および先天性ェプーリスは PTAA 染色陰 性, PAS 染色陽性, でこれらの顆粒は lysosome に似 るとしている．河合ら（1973）は mitochondria 説をと っている。

われわれの症例に打いては光学顕微鏡のレベルで顆粒 細胞性笳芽腫と診断した。その所見では歯原説を肯定で きるよらなものは何ら認められなかった．また筋原説を 裏付けるよらなグリコーゲンや横紋も見られなかった。 それゆえにその起因について何ら知見がえられなかった が, 先天性エプーリスの組織学的性状は未だ未解決の点 が多く, 今後さらに追究される必要がある.いつれにし てもこの腫瘍の発生頻度はきわめて少なく, そのため臨 床医は腫瘍検索の各種の準備に不徹底な結果を招来しや すい，われわれの症例も酵素化学的・電顕的あるいは組 織培養などによる検索が行われなかったので, 顆粒細胞 ならびに顆粒の性状についての多くの知見は得られなか った.

\section{結 語}

われわれは新生女児の上顎左側前米部凷肉に発現した 先天性エプーリスの 1 症例を報告した。

腫湯は有茎性で, ほぼ球状, 桜桃大の大きさで, 生後 16 日目に自然脱落した。組織学的には Sternbergなど の顆粒細胞性筋芽腫に一致し, 細胞は平均 $50 \times 20 \mu$ の 大きさを有し，原形質内にはエオジンで资染する多数の 顆粒を有し，それらはPAS 染色陽性であるが唾液消化 反応では陰性の性状を示した。また腫瘍内には上皮成 分・石灰化，筋横紋などの所見はなかった。

\section{文献}

1) Neumann, E.: Ein Fall von congenitaler Epulis. Arch Heilk 12 : 189 1871. 2) より引 用.

2) Custer, R. P., Fust, J. A.: Congenital epulis. Am J Clin Path 22 : 1044 1053 1952.

3) Bhaskar, S. NR., Akamine, R. : Congenital epulis (Congenital granular cell fibroblastoma). J Oral Surg $8: 517 \sim 5231955$.

4) 加藤清治 : 先天的に発生せる米蹒腫の 1 例 (抄). 日本之歯界 186 : 5031935.

5）小早川庸造, 他：先天性ェプーリスの 1 例につい て(抄). 口科誌 $5: 3311956$.

6）松田繁一郎, 他：先天性ェプーリスの 1 例につい
て. 口病誌 $22: 193 \sim 1971955$.

7）高橋庄二郎, 他：先天性エプーリスの 1 例. 歯科 学報 $62: 55 \sim 591962$.

8）木村一婎, 他 : 先天性エプーリスの 1 例(抄). 口 外誌 $9: 3081963$.

9）清水正嗣，他：先天性エプーリスの 1 例(抄). 病誌 $35: 6821968$.

10）枝重夫, 他: 先天性エプーリスの 1 症例. 病理 組織的および電子顕微鏡的研究. 歯科学報 70 : 1469〜1474 1970.

11）坂本忠幸，他：新生児下䫇前茵部に見られた先天 性ェプーリスについて(抄). 日口外誌 $16: 243$ 1970.

12）西島克己, 他 : 先天性ェプーリスの 1 例. 小児歯 誌 $9: 5 \sim 91971$.

13）河村正昭, 他：先天性エプーリスの 1 例(抄). 口 科誌 $20: 8961971$.

14）增田正樹, 他：先天性エプーリスの 1 例. 日ロ外 誌 $17: 524 \sim 5271971$.

15) Crane, A. R., Tremblay, R. G.: Myoblastoma (granular cell myoblastoma or myoblastic myoma). Am J Path $21: 357 \sim 3751945$.

16) Sternberg, C., in discussion of F. Klinger : Über die sogenanten unreifen, nicht quergestreifen Myoblastenmyoma. Verhandl d deutsch path Gesellsch $23: 376 \sim 3821928$.

17) Abrikossoff, A. J.: Weitere Untersuchungen über Myoblastenmyoma. Virchow Arch f Path Anat $280: 728 \sim 7401931$.

18）塩田重利，他：顆粒細胞性笳芽細胞腫の 2 例およ び文献的考察. 口外誌 $17: 399 \sim 4071971$.

19) Feyter, F.: Über die granulären neurogenen Gewächse. Beitr Path Anat $110: 181 \sim 207$ 1949.

20) Pearse, A. G. E.: The histogenesis of granular cell myoblastoma (granular-cell fibroblatoma). J Path Bact $62: 351 \sim 3621952$.

21) Bangle, R., Jr.: An early granular-cell myoblastoma confined with a small peripheral myeliated nerve. Cancer 6:790 793 1954.

22) Bauer, W.H., Bauer, J. D. : The so-called "Congenital epulis" OS OM OP $6: 1065 \sim 1071$ 1953.

23）河合 幹, 他：顆粒細胞エナメル上皮腫の 1 例. 日口外誌 $19: 375 \sim 3841973$.

24) Navarrete, A. R., Smith, M.: Ultrastructure of granular cell ameloblastoma. Cancer $27: 9$ 48〜955 1971. 